good supply of able students, the Institute is also well placed to oxperiment with studies which span conventional boundaries. But it would be still more exciting if it were to attempt to work out ways of giving technology a more purposeful place than it has at present in modem socicty. Why should not M.T.T. conecrn itself as much with the problems of urban technology as with those of reaching tho Moon? Tdeally, Mr. Johnson should set out to give M.I.T. the means of helping socicty to decido what uses to make of science and technology. His predecessors have accomplished a lot already, but a greal, deal remains to be done.

\section{MORE BUREAUCRATS}

$\mathrm{S}^{\mathrm{o}}$ far as it goes, the report of the Civil service Commissioners for 1965 is eheorful about the recruitment of scientists to the British Civil Service. Of tho 107 candidates successful in the compotition for entry into the Administrative Class-the members of which eventually come to inhabit what are called the corridors of power - - no fewer than nine are said to be endowed with a scientific training. The Commissioners say that this was a "marked improvement" on previous years, but plainly there is a long way to go before present methods of recruitment will ensure that the mainstream of the Civil Service is adequately supplied with competent scientists. At the samo time, thore is continuing anxicty about the recruitment of cupablo scientistis into the Seientific Class. Here the difficulty is not so much an absolute shortage of numbers as a shortage of candidates of really out. standing quality. This does not necessarily mean that the Govornment research establishments are starved of really able men, for the recruitment of professional scientists to the Civil Service usually entails a period of unestablished service which does not count in the Commissionors' statistics. But evidently there is a lack of really able professionals willing to settle down in Government service. Even though the rapid growth of recent years is clearly part of the eause of the Commissioners" anxiety, things could obviously be better than they are.

Here, as in many other parts of British public administration, the remedy is probably to be found in grouter flexibility. Thus the recruitment of scientists to the Administrative Class would be enormously improved if only the Civil Service as a whole would make fullor use of the arrangements which now exist for the transfer of mon and women from one class to another. In 1965 there were fewer than a dozen transfers of this kind, yet the Government laboratorios are now well supplied with experienced administrators ready arid able to spread their wings. Both classes - the Administrative and tho Scienti. fic -would be botter off if thoro were a more ready interchange between them. In a very simnilar way, recruitment to the Scientific Class would be improved if it, wore easier than it is at present for professional eivil servants to retain a sense of kinship with the scientific discipline to which they belong. Thore needs to be a groater traffic of people between the research establishments and the universities and industry. Sabbatical leave ought to be a necessity, not a luxury. And some of the humdrum customs of publio service ought to be abolished. The irony is that British public laboratories have never before been so well stocked with exciting problems to bo tackled.

\section{COMMONSENSICAL ENGLISHMEN}

\section{The English Paracelsians}

By Allen G. Debus. (Oldbourne History of Science Library.) Pp. $222+7$ plates. (London: Oldbourne Book Co., Ltd., 1965.) 45s. not.

7 HE sixteenth century was rich in passionate personalities who delighted in being at the storm centre of controversy and whose life and work have aroused eithor adulation or distaste ever since their own day. Was Cardan, the astrologer-physician, a great mathematician or a fraudulent plagiarist? Was Giordano Bruno a Copernican martyr or a magician and pantheistic heretic, Paracelsus the founder of modern chemistry or an alchemist sunk in mystic and incomprehensible theory? It all depends on ono's temperament, and neither Paracelsus nor any of the othors have ever lackod defenders. Those who find these mystic and magical aspects of the sixteenth century distasteful and of doubtful value in the history of modern thought can consols themselves with the reflexion that the later contemporaries and successors of those followers of the Hermetic tradition (as Frances Yates has recently taught us to consider it) found their books difficult to understand and even nonsensical.

Mr. Debus belongs to the younger generation of historians of science, already in revolt against the rationalist views of his post-War predecessors; he would like to see in Faracolsus a dominant leader in the emergence of moder chemistry. Had ho chosen to discuss the Continental Paracelsans of the period before 1650 he would have found, as he himself says, much detailed and solid evidence of Puracolsan influence. But circumstances have led him to write about Paracelsanism in England before 1640, and he is too good a scholar not to recognize that the English even then wore too sceptical of high-flown mystic or metaphysical theory to be Paracelsans in any real sense, and, as here emorges, Paracelsan ideas were of negligible importance in Elizabethan and Jacobean England.

Tt must be romembercd that then, as now, Paracelsus was a very inaccessible author. Few Englishmen could (or can) understand the curious mixture of Schweizdoutsch and Latin in which Paracelsus wrote, and most of his works have never been translated into English. (Only two small works were so translated in this period.) In addition, Paracelsus's theory is difficult to understand; ho expressed himself obscurcly and is often inconsistent. Only two Englishmen ever seem to have been direct followers of Paracolsus: Bostocke and Fludd. (More refer to his theory only to insist they cannot understand it, and a few accepted a diluted version promulgated by later Continental Paracelsans.) Bostocke was an extremely obscure Elizabethan mainly remembered for his comparison of Copernicus and l'aracelsus (which Mr. Dobus makes less clear because ho does not know the Flizabethan usage of 'stars' for 'planets'). Robert Fludd, whom Mr. Debus has studied at some length, was the Jacobean expositor of a "Mosaic philosophy', a blend of Renaissance science and speculative mysticism which was extensively attacked on the Continent, notably by Mersenne and Gassendi, but was virtually ignored in England. The mystic ehemistry to bo found in this period belongs to the older al. chemical tradition of George Ripley and Thomas Norton; it was not until the 1650 's that English mystic chemistry received a new stimulus from the work of Van Helmont. It is to be hoped that Mr. Debus may give us an examination of English Helmontians, who are many and varied.

As The English Paracelsians amply demonstrates, English modical men and apothecaries accepted the "new' chomical remedies and drugs for which Paracolsus had claimed so much without regarding them as necessarily Paracelsan. Partly this is becauso they recognized that chemical remedies were older than Paracelsus, and purtly bceause they derived thom from followers of Paracelsus in whom the pure Paracelsan doctrine was much diluted. 